\title{
Effects of Genetic Polymorphism of Metabolic Enzymes, Nutrition, and Lifestyle Factors on DNA Adduct Formation in Lymphocytes
}

\author{
Yanping WANG*, Masayoshi ICHIBA, Minako IYADOMI, Jiusong ZHANG \\ and Katsumaro TOMOKUNI
}

Department of Community Health Science, Saga Medical School, Nabeshima, Saga 849-8501, Japan

Received June 8, 1998 and accepted August 6, 1998

\begin{abstract}
Although cigarette smoking is one major determinant of lung carcinogenesis, not all smokers develop cancer. This phenomenon is due to individual variation in genetic susceptibility to carcinogens, nutrition, and lifestyle. Previous studies have shown that genetic polymorphism of metabolic enzymes and plasma micronutrients are associated with lung cancer risk. DNA adducts may serve as a molecular dosimeter for exposure to carcinogens. In this cross-sectional study, we analyzed the blood samples of 158 subjects to evaluate the effects of polymorphisms of cytochrome P450 1A1 (CYP1A1), glutathione S-transferase M1 (GSTM1), T (GSTT), $\mathbf{N}$-acetytransferase 2 (NAT2), and aldehyde dehydrogenase 2 (ALDH2) as well as the effects of plasma $\beta$-carotene and $\alpha$ tocopherol on lymphocyte DNA adducts measured by ${ }^{32} \mathrm{P}$-postlabeling analysis. The DNA adduct level of smokers (mean $\pm \mathrm{SD}, 1.26 \pm 0.79 / 10^{8}$ nucleotides) was significantly higher than that of nonsmokers $(0.87 \pm 0.33, P=0.007)$. Smokers with CYP1A1 minor homozygotes and GSTM1 null genotypes had a significantly higher level of DNA adducts than those without $(P=0.027$ for homozygotes, $\mathbf{P}=\mathbf{0 . 0 4 9}$ for heterozygotes). Smokers with NAT2 minor homozygotes also tended to have a higher DNA adduct level than those with heterozygotes and wild alleles, but the difference was not statistically significant. The DNA adduct level of smokers with ALDH2 heterozygotes was significantly higher than that of smokers with minor homozygotes $(P=0.045)$. When smokers were divided into "high" and "low" groups according to mean level of plasma $\beta$-carotene or $\alpha$-tocopherol, in the low $\beta$-carotene group, the subjects with CYP1A1 minor homozygotes had higher DNA adduct levels than those with other CYP1A1 genotypes. Smokers with GSTT null genotype and high $\beta$ carotene tended to have a higher DNA adduct level than those with GSTT present and high $\beta$ carotene $(P=0.07)$, and those with GSTT null genotype and low $\beta$-carotene $(P=0.07)$. There was weak correlation between DNA adduct level and number of cigarettes smoked per day in the low plasma $\beta$-carotene group $(r=0.28, n=36, p<0.1)$. These results suggested that polymorphisms of CYP1A1, GSTM1, T, NAT2, and ALDH2, and plasma $\beta$-carotene may modulate the level of DNA adducts.
\end{abstract}

Key words: Cigarette smoking, DNA adducts, Genetic polymorphism, $\beta$-Carotene, $\alpha$-Tocopherol

\footnotetext{
*To whom correspondence should be addressed.
} 


\section{Introduction}

Individual differences in susceptibility to chemical-induced carcinoma are in part ascribable to genetic differences of metabolic enzymes, nutrition, and lifestyle. DNA adducts, as biomarkers for biologically effective dose of carcinogens, have been used to study the relationship between carcinogen exposure and cancer mechanisms. The question whether formation of environmental carcinogens-DNA adducts is modulated by host polymorphism has been under extensive investigation.

Certain carcinogens, namely polycyclic aromatic hydrocarbons (PAH), are metabolically activated by cytochrome P450 (CYP) family enzymes in the initial oxidation step. The exon 7 Val polymorphism of CYP1A1 has been associated with increased risk of lung cancer in a Japanese population ${ }^{1,2)}$, but several studies have found no association in Caucasian populations ${ }^{3,4)}$. Glutathione Stransferase (GST) classes include important detoxification enzymes that are responsible for conjugation of electrophilic compounds to glutathione, and therefore prevent reactive intermediates binding with DNA. The polymorphism of GSTM1 is associated with high risk of lung cancer in Japanese and Caucasian populations ${ }^{1,5,6)}$. Some studies have found that GSTM1 deficiency may be associated with higher levels of DNA adducts ${ }^{7-9}$. Recently, a gene deletion polymorphism in GSTT class has been recognized, and ethnic differences in polymorphism have been found in genes ${ }^{10,11)}$. Although GSTT deficiency has been shown to influence the background rate for sister chromatid exchanges and potentiate the induction of chromosomal damage by ethylene oxide in in vitro experiments ${ }^{12,13)}$, there is little data on the effect of GSTT polymorphism on DNA adducts ${ }^{14)}$.

Polymorphism of the $\mathrm{N}$-acetytransferase 2 (NAT2) gene has been associated with an increased risk of developing certain cancers ${ }^{15,16)}$. It has been suggested that people with slow acetylators may have higher levels of DNA adducts. Previous studies have indicated that polymorphism has no significant effects on DNA adducts ${ }^{8,17)}$.

Acetaldehyde is suspected to be the ultimate carcinogen in alcohol-related carcinogenesis. A recent report has shown that alcoholics and habitual drinkers with the heterozygous genotype of low $\mathrm{K}_{\mathrm{m}}$ aldehyde dehydrogenase 2 (ALDH2) have a significantly higher risk of esophageal cancer ${ }^{18)}$. Other studies have indicated that acetaldehyde has many effects on health, including cytotoxicity ${ }^{19)}$, DNA damage ${ }^{20)}$, and carcinogenesis in rodents ${ }^{21}$. The question whether polymorphism of ALDH2 and alcohol drinking have affect
DNA adduct formation remains to be answered.

Relationship between combination of genetic polymorphisms and blood antioxidants and DNA adduct formation has not been reported so much ${ }^{22-24)}$. In vitro and in vivo experiments have indicated that $\beta$-carotene and $\alpha$ tocopherol mediate PAH metabolism and PAH-DNA adduct formation $^{25-27)}$. It has been shown that PAH-DNA adduct levels are significantly inversely correlated with serum cholesterol-adjusted vitamin $\mathrm{E}$ and $\beta$-carotene levels in smokers with GSTM1 null genotype, and interaction of $\beta$ carotene and $\alpha$-tocopherol was also found in one of two studies on DNA adducts ${ }^{22,24)}$. The above studies also showed that $\beta$-carotene and $\alpha$-tocopherol may modulate DNA adducts, and the effects might be influenced by GSTM1 genotype.

In a previous study, we did not find that concentrations of plasma $\beta$-carotene and $\alpha$-tocopherol were significantly associated with DNA adduct levels in lymphocytes ${ }^{23)}$.

In the present study, we evaluated the effects of (1) genetic polymorphisms of CYP1A1, GSTM1, and T1, NAT2, and ALDH2, (2) plasma $\beta$-carotene and $\alpha$-tocopherol, and (3) lifestyle (cigarette smoking and alcohol consumption) on DNA adduct levels, increasing the number of subjects from 104 to 158 .

\section{Subjects and Method}

\section{Subjects}

One hundred and fifty-eight Japanese male workers (age; $18-58$ years), who were employed in a food products factory, agreed to participate in this study. Each subject's daily cigarette consumption, alcohol consumption, and food intake were assessed by means of questionnaires. Nonsmokers and smokers were defined as persons who had not smoked for at least one year and persons who had been smoking for more than half a year, respectively. The daily nicotine intake of smokers was calculated from the data in a tobacco catalog (Japan Tobacco Inc., August 1994). A survey on the intake frequency of green/yellow vegetables and fruits was also conducted. For each food item, participants were required to choose one of four possible responses: almost never, 2 3 times per week, 4-5 times per week and every day.

\section{Analysis}

Blood specimens $(7 \mathrm{ml})$ were obtained using EDTA tubes in the morning. After centrifuging, plasma was promptly separated and stored at $-80^{\circ} \mathrm{C}$. The modified HPLC method proposed by Miller ${ }^{28,29)}$ was used for $\beta$-carotene and $\alpha$ - 
tocopherol measurements. The HPLC system was model LC-9A (Shimadzu Co., Kyoto, Japan), and the column was shim-pack CLC-ODS M (4.6 mm $\times 15 \mathrm{~cm}$, Shimadzu Co.). Two spectrophotometric detectors (SPD-6AV and SPD-6A, Shimadzu. Co) were set at $453 \mathrm{~nm}$ and $285 \mathrm{~nm}$.

Urinary cotinine was measured by the HPLC method $^{30)}$, and the cotinine profile was adjusted with urinary creatinine. Urinary creatinine was measured by the Jaffe's method.

Lymphocytes were separated by Ficoll-Paque (Pharmacia LKB Biotechnology) and used for measurement of DNA adducts. DNA was isolated by a modification method using RNAase, protease digestion, and ethanol precipitation ${ }^{31}$. DNA products were stored at $-80^{\circ} \mathrm{C}$. The nuclease $\mathrm{P} 1$ modification of the ${ }^{32} \mathrm{P}$-postlabeling method was used to measure aromatic DNA adducts ${ }^{32)}$. Five $\mu \mathrm{g}$ of DNA was digested with micrococcal nuclease, spleen phosphodiesterase, and nuclease P1. The product was dried and taken up in total 2 $\mu \mathrm{l}$ of T4 polynucleotide kinase labeling mixture containing $\left[\boldsymbol{\gamma}^{32} \mathrm{P}\right]$ ATP. The labeled samples were spotted on thin layers of polyethyleneimine-cellulose (Macherry-Nagel, Germany) for multidirectional chromatography using three solvent systems. Adducts were visualized using a Bio-Image Analyzer (BAS2000; Fuji Photo Film Co., Tokyo, Japan) after exposing TLC plates to the films. An area including adducts on the TLC plates was counted, and background levels measured in the same plates were subtracted. The measurements were repeated 2-3 times for each sample. The results were expressed as the total number of adducts per $10^{8}$ normal nucleotides.

Polymorphism of CYP1A1 was detected by the restriction fragment length method proposed by Oyama et al. ${ }^{33)}$, indicating that the exon 7 Ile-Val polymorphism results in a population of three subgroup genotypes; Ile/Ile, Ile/Val, and Val/Val. Polymorphisms of GSTM1 and T were detected by the methods of Groppi et al. ${ }^{34)}$ and Nelson et al. ${ }^{11)}$, respectively. The presence or deletion of the genes results in a population of subgroups corresponding to genotype GSTM1 or T present $(+)$ and null $(-)$. Polymorphism of NAT2 was detected according to the method of Hou et al. ${ }^{8}$. Subjects were divided into three subgroups according to the restriction analysis of PCR products with KpnI, TaqI, and BamHI. RR genotype is for the wild-type allele, and RS is any one of the three point mutations. SS genotype is for minor homozygotes. ALDH2 polymorphism was detected according to the method of Takeshita et $\mathrm{al}^{35)}$, and populations were divided into three subgroups of ALDH2 A1/A1, A1/ $\mathrm{A} 2$, and $\mathrm{A} 2 / \mathrm{A} 2$.

\section{Statistical analysis}

The data on both DNA adducts and vitamin levels were log-transformed before statistical analysis. Significant differences in DNA adduct levels were assessed using ANOVA and unpaired Student's t tests. Partial and Pearson's correlation were utilized for analyses.

\section{Results}

In this cross-sectional study, $49 \%$ of the 158 male subjects were smokers. The characteristics and analytic variables for smokers and nonsmokers are presented in Table 1. The mean ages of smokers and nonsmokers were almost the same. On average, smokers had consumed about one pack of cigarettes per day for about 18 years. The levels of nicotine intake and urinary cotinine in smokers were significantly

Table 1. Study characteristics and analytic variables

\begin{tabular}{lccc}
\hline & Smokers & Nonsmokers & All \\
& $\mathrm{n}=77$ & $\mathrm{n}=81$ & $\mathrm{n}=158$ \\
\hline Age & $39.6 \pm 14.0$ & $40.7 \pm 13.7$ & $40.1 \pm 13.8$ \\
Cigarettes/day & $20.1 \pm 8.6^{*}$ & - & - \\
Years of smoking & $17.8 \pm 12.6^{*}$ & - & - \\
Nicotine intake per day $(\mathrm{mg})$ & $18.4 \pm 9.8$ & - & - \\
Urinary cotinine $(\mu \mathrm{g} / \mathrm{g}$ creatinine) & $911.0 \pm 953.2^{*}$ & $18.2 \pm 36.3$ & $456.3 \pm 802.9$ \\
Green/yellow vegetable intake frequency/month & $11.6 \pm 2.9$ & $12.2 \pm 3.0$ & $11.9 \pm 3.0$ \\
Fruit intake frequency/month & $10.8 \pm 3.2$ & $11.5 \pm 3.4$ & $11.2 \pm 3.3$ \\
Plasma $\beta$-carotene $\mu \mathrm{g} / \mathrm{dl}$ & $26.3 \pm 17.0 *$ & $34.5 \pm 20.2$ & $30.5 \pm 19.1$ \\
Plasma $\alpha$-tocopherol $\mathrm{mg} / \mathrm{dl}$ & $1.09 \pm 0.28$ & $1.15 \pm 0.37$ & $1.12 \pm 0.33$ \\
Drinkers $(\%)$ & $67 \%$ & $63 \%$ & $65 \%$ \\
Alcohol intake $(\mathrm{g} / \mathrm{day})$ & $21.4 \pm 26.4$ & $17.2 \pm 21.8$ & $19.3 \pm 24.2$ \\
\hline
\end{tabular}

*; $\mathrm{P}<0.01$, comparison with nonsmoker. 
Table 2. DNA adduct levels in smokers and nonsmokers with different genotypes

\begin{tabular}{|c|c|c|c|c|}
\hline \multicolumn{2}{|c|}{ Genotypes } & \multirow{2}{*}{$\begin{array}{c}\text { Smokers } \\
1.22 \pm 0.73 \\
{[46]}\end{array}$} & \multirow{2}{*}{$\begin{array}{c}\text { Nonsmokers } \\
0.89 \pm 0.27 \\
{[46]}\end{array}$} & \multirow{2}{*}{$\begin{array}{c}\text { All } \\
1.06 \pm 0.57 \\
{[92]}\end{array}$} \\
\hline CYP1A1 & Ile/Ile & & & \\
\hline & Ile/Val & $\begin{array}{c}1.25 \pm 0.86 \\
{[27]}\end{array}$ & $\begin{array}{c}0.86 \pm 0.40 \\
{[32]}\end{array}$ & $\begin{array}{c}1.04 \pm 0.67 \\
{[59]}\end{array}$ \\
\hline & $\mathrm{Val} / \mathrm{Val}$ & $\begin{array}{c}1.73 \pm 1.02 \\
{[4]}\end{array}$ & $\begin{array}{c}0.75 \pm 0.21 \\
{[2]}\end{array}$ & $\begin{array}{c}1.40 \pm 0.94 \\
{[6]}\end{array}$ \\
\hline \multirow[t]{2}{*}{ GSTM1 } & Present & $\begin{array}{c}1.39 \pm 0.84 * \S \\
{[48]}\end{array}$ & $\begin{array}{c}0.87 \pm 0.35 \\
{[46]}\end{array}$ & $\begin{array}{c}1.13 \pm 0.69 \\
{[94]}\end{array}$ \\
\hline & Null & $\begin{array}{c}1.04 \pm 0.65 \\
{[29]}\end{array}$ & $\begin{array}{c}0.87 \pm 0.31 \\
{[35]}\end{array}$ & $\begin{array}{c}0.95 \pm 0.50 \\
{[64]}\end{array}$ \\
\hline \multirow[t]{2}{*}{ GSTT1 } & Present & $\begin{array}{c}1.16 \pm 0.77 \\
{[42]}\end{array}$ & $\begin{array}{c}0.89 \pm 0.33 \\
{[33]}\end{array}$ & $\begin{array}{c}1.01 \pm 0.58 \\
{[94]}\end{array}$ \\
\hline & Null & $\begin{array}{c}1.38 \pm 0.81 * \\
{[35]}\end{array}$ & $\begin{array}{c}0.83 \pm 0.34 \\
{[29]}\end{array}$ & $\begin{array}{c}1.13 \pm 0.96 \\
{[64]}\end{array}$ \\
\hline \multirow[t]{3}{*}{ NAT2 } & RR & $\begin{array}{c}1.23 \pm 0.78 \\
{[37]}\end{array}$ & $\begin{array}{c}0.91 \pm 0.29 \\
{[38]}\end{array}$ & $\begin{array}{c}1.08 \pm 0.61 \\
{[75]}\end{array}$ \\
\hline & RS & $\begin{array}{c}1.09 \pm 0.68 \\
{[28]}\end{array}$ & $\begin{array}{c}0.84 \pm 0.39 \\
{[31]}\end{array}$ & $\begin{array}{c}0.96 \pm 0.56 \\
{[59]}\end{array}$ \\
\hline & SS & $\begin{array}{c}1.61 \pm 0.96 * \\
{[11]}\end{array}$ & $\begin{array}{c}0.83 \pm 0.26 \\
{[12]}\end{array}$ & $\begin{array}{c}1.20 \pm 0.61 \\
{[23]}\end{array}$ \\
\hline \multirow[t]{3}{*}{ ALDH2 } & $\mathrm{A} 1 / \mathrm{A} 1$ & $\begin{array}{c}1.21 \pm 0.77 \\
{[39]}\end{array}$ & $\begin{array}{c}0.88 \pm 0.31 \\
{[45]}\end{array}$ & $\begin{array}{c}1.04 \pm 0.59 \\
{[84]}\end{array}$ \\
\hline & $\mathrm{A} 1 / \mathrm{A} 2$ & $\begin{array}{c}1.35 \pm 0.81 * \S \\
{[31]}\end{array}$ & $\begin{array}{c}0.81 \pm 0.29 \\
{[28]}\end{array}$ & $\begin{array}{c}1.10 \pm 0.68 \\
{[59]}\end{array}$ \\
\hline & $\mathrm{A} 2 / \mathrm{A} 2$ & $\begin{array}{c}0.84 \pm 0.56 \\
{[6]}\end{array}$ & $\begin{array}{c}1.01 \pm 0.52 \\
{[8]}\end{array}$ & $\begin{array}{c}0.94 \pm 0.52 \\
{[14]}\end{array}$ \\
\hline \multicolumn{2}{|l|}{ All } & $\begin{array}{c}1.26 \pm 0.79 * \\
{[77]}\end{array}$ & $\begin{array}{c}0.87 \pm 0.33 \\
{[81]}\end{array}$ & $\begin{array}{c}1.06 \pm 0.63 \\
{[158]}\end{array}$ \\
\hline
\end{tabular}

DNA adduct level was expressed as adducts $/ 10^{8}$ nuleotides, and one data was missed for NAT2 and ALDH2. *; P<0.01 comparison with nonsmokers. s; $\mathrm{P}<0.05$ comparison with GST ( - ) or ALDH2 A2/A2 in smokers.

higher than those in nonsmokers. In smokers, urinary cotinine levels were significantly correlated with the number of cigarettes $(r=0.59, \mathrm{P}<0.0001)$. Though intake frequencies of green/yellow vegetables and fruits did not differ between smokers and nonsmokers, the level of plasma $\beta$-carotene in smokers was lower than that in nonsmokers $(\mathrm{P}=0.003)$. The plasma $\alpha$-tocopherol level of smokers was also slightly lower than that of nonsmokers. In all subjects, plasma $\beta$-carotene and $\alpha$-tocopherol were weakly correlated $(\mathrm{r}=0.22, \mathrm{P}<0.01)$. The proportion of drinkers among the smokers was almost as high as that among the nonsmokers. The alcohol intake per day in smokers was similar to that in nonsmokers.

The effects of genetic polymorphisms of metabolic enzymes on lymphocyte DNA adduct levels are shown in Table 2. Smokers had a significantly higher mean aromatic

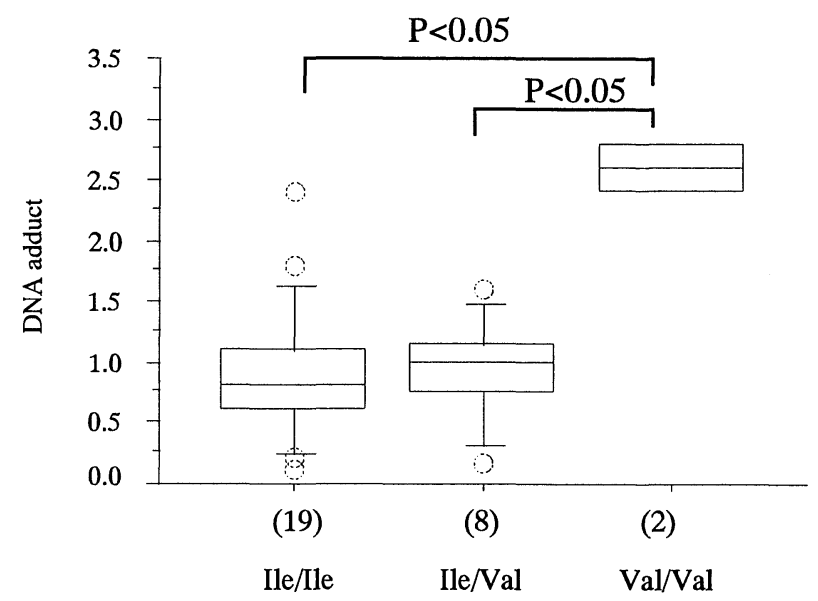

Fig. 1. Comparison of DNA adduct levels with respect to CYP1A1 genotypes in GSTM1 null smokers.

DNA adduct levels are expressed as adducts $/ 10^{8}$ nucleotides. Boxes indicate $25 \%$ and $75 \%$, and the median level is indicated with a horizontal line.

DNA adduct level in lymphocytes than nonsmokers $(\mathrm{P}=0.007)$. When subjects were classified by genotype, the DNA adduct levels in smokers and nonsmokers were significantly different among the populations with GSTM1 present, T null, NAT2 SS, and ALDH2 A1/A2 allele. In smokers, DNA adduct level with CYP1A1 Val/Val was higher than those with Ile/Ile and Ile/Val genotypes. The DNA adduct level of smokers with GSTM1 present was significantly higher than that of smokers with GSTM1 null $(\mathrm{P}=0.007)$. DNA adduct level of smokers with ALDH2 A1/ A2 genotype was significantly higher than that of smokers with $\mathrm{A} 2 / \mathrm{A} 2$ genotypes. The smokers with $\mathrm{A} 2 / \mathrm{A} 2$ genotypes were all non drinkers. DNA adduct level of smokers with GSTT null was slightly higher than those of smokers with GSTT present $(\mathrm{P}=0.12)$. The DNA adduct level of smokers with NAT2 SS was slightly higher than that of smokers with RS genotype $(\mathrm{P}=0.08)$.

The combined effect of polymorphisms of CYP1A1 and GSTM1 null on DNA adduct levels in smokers is shown in Fig. 1. In smokers with GSTM1 null genotype, the DNA adduct level of subjects with CYP1A1 Val/Val genotypes (mean $\pm \mathrm{SD}, 2.60 \pm 0.28 / 10^{8}$ nucleotides) was significantly higher than that of subjects with CYP1A1 Ile/Val (0.95 \pm $0.42, \mathrm{P}<0.05)$ and Ile/Ile $(0.91 \pm 0.55, \mathrm{P}<0.05)$ genotypes. The DNA adduct level of smokers with CYP1A1 Val/Val and GSTM1 null genotype was also markedly higher than that of smokers with CYP1A1 Val/Val and GSTM1 present genotype $(0.85 \pm 0.14, n=2)$. Since there were only four 


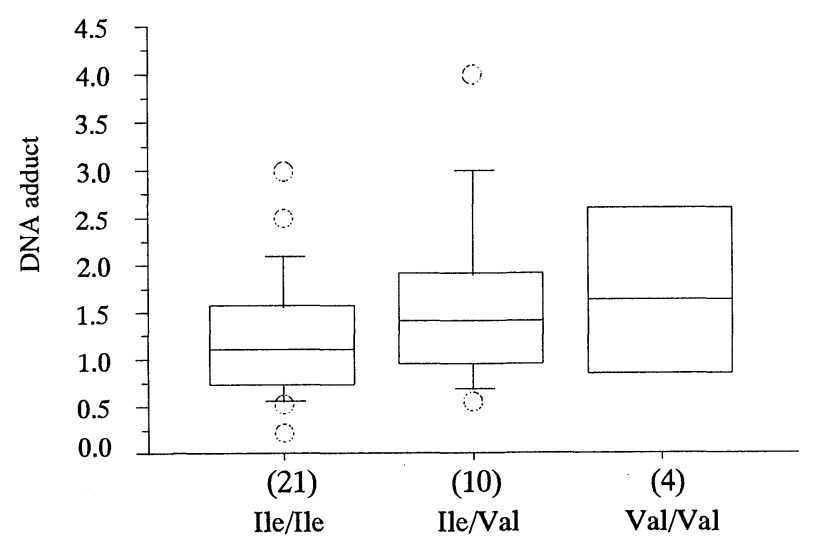

Fig. 2. Comparison of DNA adduct levels with respect to CYP1A1 genotypes in GSTT null smokers.

DNA adduct levels are expressed as adducts $/ 10^{8}$ nucleotides. Boxes indicate $25 \%$ and $75 \%$, and the median level is indicated with a horizontal line.

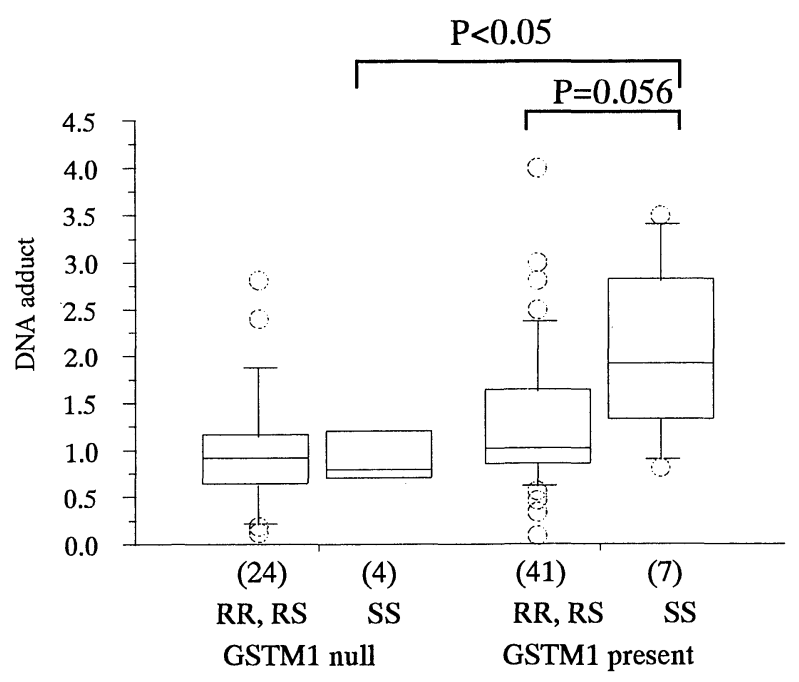

Fig. 3. Effects of GSTM1 and NAT2 genotypes on DNA adduct levels in smokers.

DNA adduct levels are expressed as adducts $/ 10^{8}$ nucleotides. Boxes indicate $25 \%$ and $75 \%$, and the median level is indicated with a horizontal line.

smokers with CYP1A1 Val/Val genotype (two with GSTM1 null and two with GSTM1 present), the observed difference was not statistically significant. In smokers with GSTM1 present, the DNA adduct level of CYP1A1 Val/Val genotype was not significantly different from that of other genotypes. The above differences were not observed among nonsmokers.

The combined effect of polymorphism of CYP1A1 and

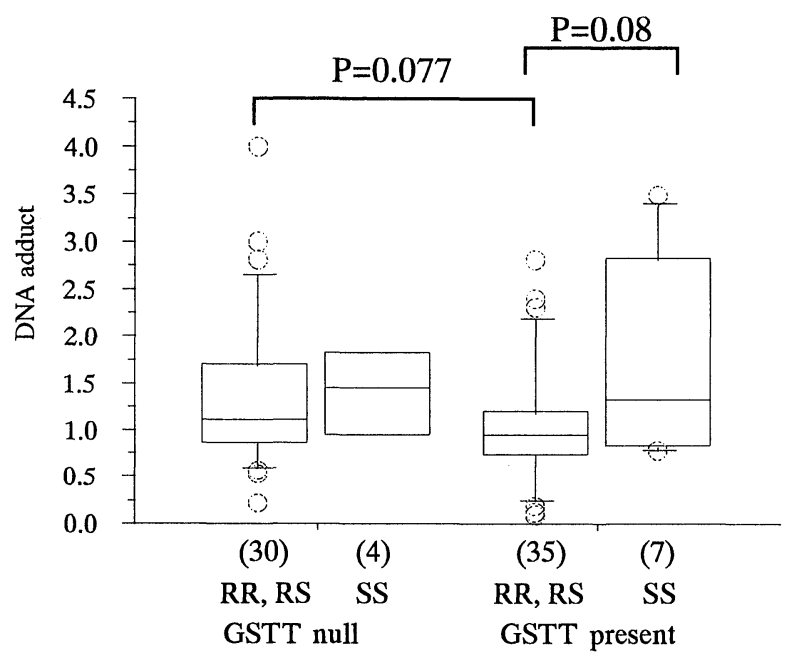

Fig. 4. Effects of GSTT and NAT2 genotypes on DNA adduct levels in smokers.

DNA adduct levels are expressed as adducts $/ 10^{8}$ nucleotides. Boxes indicate $25 \%$ and $75 \%$, and the median level is indicated with a horizontal line.

GSTT null genotype on DNA adduct levels in smokers is shown in Fig. 2. Within the GSTT null group, although the difference was not significant, smokers with CYP1A1 Val/ Val $(1.73 \pm 1.03)$ tended to have a higher DNA adduct level than those with Ile/Val (1.57 \pm 0.86$)$ and Ile/Ile (1.22 \pm 0.67$)$ genotypes. This tendency was not found in nonsmokers.

The combined effect of polymorphism of GSTM1 and NAT2 on DNA adduct levels in smokers is shown in Fig. 3. Within the GSTM1 present group, smokers with NAT2 SS had significantly higher DNA adduct levels $(1.99 \pm 0.99)$ than those with NAT2 RR or RS genotype (1.29 \pm 0.77 , $\mathrm{P}=0.056$ ).

The combined effect of polymorphism of GSTT and NAT2 on DNA adducts in smokers is shown in Fig. 4. In smokers with GSTT present group, the subjects with NAT2 SS had a slightly higher DNA adduct level $(1.74 \pm 1.14)$ than those with NAT2 RR or RS genotype (1.04 $\pm 0.62, \mathrm{P}=0.08)$. In smokers with NAT2 RS or RR genotype, the DNA adduct level of GSTT null $(1.34 \pm 0.83)$ was slightly higher than that of GSTT present $(1.04 \pm 0.62, \mathrm{P}=0.077)$. These differences between genotypes were not found among nonsmokers.

Effects of plasma $\beta$-carotene and $\alpha$-tocopherol on DNA adduct levels in smokers are shown in Table 3. Subjects were divided into four subgroups according to their $\beta$ carotene and $\alpha$-tocopherol concentrations (lower or higher than median concentration). DNA adduct levels of smokers 
Table 3. Comparison of DNA adduct levels with respect to plasma $\beta$ carotene and $\alpha$-tocopherol levels in smokers II

\begin{tabular}{cccc}
\hline & Low $\beta$-carotene & High $\beta$-carotene & All \\
\hline Low $\alpha$-tocopherol & $1.25 \pm 0.83$ & $1.43 \pm 1.12$ & $1.30 \pm 0.91$ \\
& {$[28]$} & {$[12]$} & {$[40]$} \\
High $\alpha$-tocopherol & $1.02 \pm 0.47$ & $1.38 \pm 0.72$ & $1.20 \pm 0.63$ \\
& {$[18]$} & {$[19]$} & {$[37]$} \\
\hline All & $1.16 \pm 0.71$ & $1.40 \pm 0.88$ & $1.26 \pm 0.79$ \\
& {$[46]$} & {$[47]$} & {$[77]$} \\
\hline
\end{tabular}

I; Smokers were divided according to whether their $\beta$-carotene and $\alpha$ tocopherol concentrations were lower or higher than the median.

with high $\beta$-carotene were slightly higher than those of smokers with low $\beta$-carotene, but no significant difference was found.

In low $\beta$-carotene smokers, although the difference was not significant, the smokers with CYP1Al Val/Val genotype tended to have higher DNA adduct levels than the other smokers with Ile/Val $(\mathrm{P}=0.26)$ and Ile/Ile $(\mathrm{P}=0.14)$ genotypes (Fig. 5). On the other hand, for smokers with CYP1A1 Ile/ Ile genotypes, the DNA adduct level in the high $\beta$-carotene group was significantly higher than that in the low $\beta$-carotene group $(\mathrm{P}<0.05)$.

Smokers with GSTT null and high plasma $\beta$-carotene tended to have higher DNA adduct levels than those with GSTT present and high plasma $\beta$-carotene $(\mathrm{P}=0.07)$, and those with GSTT null and low $\beta$-carotene ( $\mathrm{p}=0.07$, Fig. 6 ).

The tendency for CYP1A1 and GSTT with plasma $\beta$ carotene to affect the levels of DNA adducts was not found in nonsmokers.

There was weak correlation between DNA adduct levels and number of cigarettes smoked per day in the low $\beta$ carotene group $(\mathrm{r}=0.28, \mathrm{n}=46, \mathrm{P}<0.1)$. No significant correlation between plasma $\beta$-carotene or $\alpha$-tocopherol concentration and DNA adduct levels was found in smokers or nonsmokers (even after adjusting for number of cigarettes smoked per day, or urinary cotinine concentration).

Alcohol consumption had no significant effect on the levels of DNA adducts in smokers.

\section{Discussion}

In the present Japanese cross-sectional study, as was expected, smokers with CYP1A1 Val/Val and GSTM1 null genotype had a significantly higher DNA adduct level than those with Ile/Val and Ile/Ile genotypes, and this level was

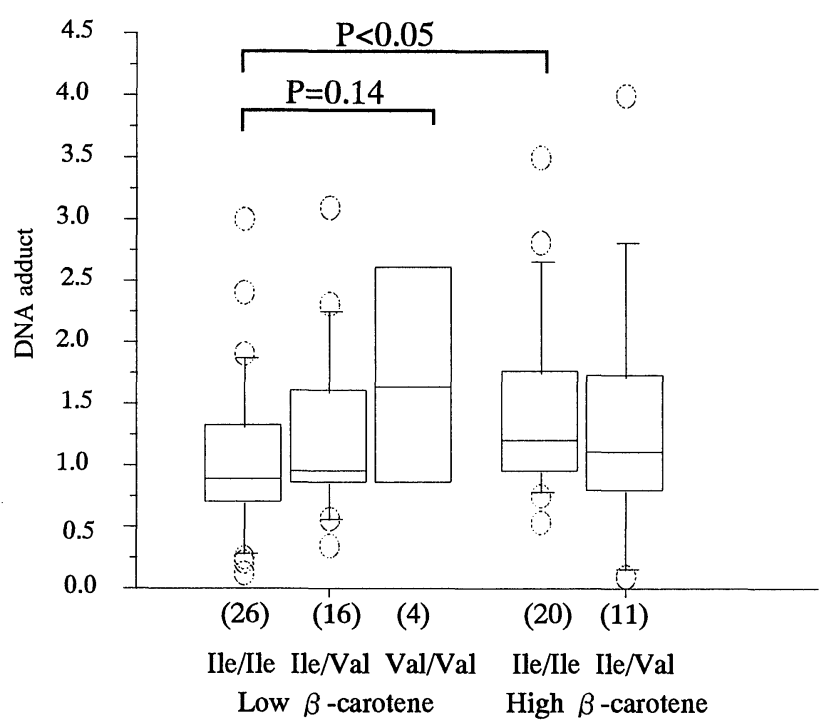

Fig. 5. The DNA adduct levels with respect to CYP1A1 genotypes and plasma $\beta$-carotene in smokers.

DNA adduct levels are expressed as adducts $/ 10^{8}$ nucleotides. Boxes indicate $25 \%$ and $75 \%$, and the median level is indicated with a horizontal line.

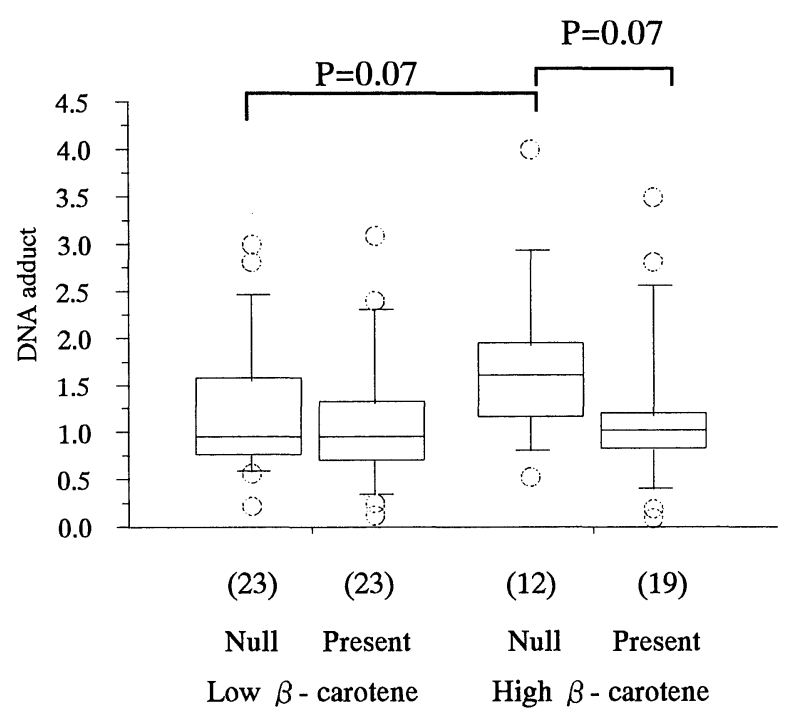

Fig. 6. The DNA adduct levels with respect to GST T genotypes and plasma $\beta$-carotene in smokers.

DNA adduct levels are expressed as adducts $/ 10^{8}$ nucleotides. Boxes indicate $25 \%$ and $75 \%$, and the median level is indicated with a horizontal line.

higher than that of smokers with CYP1A1 Val/Val and GSTM1 present genotypes. Ichiba et al. found no statistically significant association between the DNA adduct levels and the Ile-Val mutation in Swedish chimney sweeps ${ }^{7}$. Mooney 
et al. reported that the DNA adduct level of smokers with the CYP1A1 Val allele was two fold higher than that of smokers without this allele in a Caucasian population ${ }^{24)}$. However, neither studies revealed any significant combined effects of polymorphism of CYP1A1 and GSTM1 on DNA adduct levels. These results may be attributed to the very low frequency of minor homozygotes in Caucasian populations. In the present study, although there were only four smokers with CYP1A1 Val/Val genotype, genetic polymorphism of CYP1A1 combined with GSTM1 tended to be associated with the formation of carcinogens-DNA adducts. In epidemiological studies among Japanese, it has been reported that CYP1A1 exon $7 \mathrm{Val} / \mathrm{Val}$ combined with GSTM1 null genotype is associated with increased risk of lung cancer ${ }^{1,2)}$. The results of the present study support the hypothesis that the CYP1A1 minor homozygotes and GSTM1 null genotype are important factors in cancer risk.

There have been several studies concerning the effects of GSTM1 polymorphism on DNA adduct levels ${ }^{7-9}$. GSTM1 polymorphism has been associated with DNA adduct levels when combined with polymorphism of CYP1A1, NAT2 or GST P1, but GSTM1 polymorphism has not been found to be directly associated with DNA adduct level. The above results indicate that the effect of GSTM1 polymorphism on DNA adducts may be weak or confounded by other factors.

The results of the present study indicate, contrary to expectation, that smokers with GSTM1 present have a significantly higher DNA adduct level than the smokers with GSTM1 null. Although we are unable to explain this result, the finding that the urinary cotinine level of the GSTM1 present group was about two times higher than that of the null group suggests that the difference in DNA adduct level may result from different cigarettes smoke exposure.

The DNA adduct level of smokers with GSTT null was higher than that of smokers with GSTT present, as expected. This result was similar to our previous finding that subjects with a combination of GSTM1 null and T null had a higher DNA adduct level than the others in low dose cigarettes smokers ${ }^{14}$. Smokers with CYP1A1 Val/Val and GSTT null tended to have higher DNA adduct level than the other smokers, although the difference was not statistically significant. CYP1A1 Val/Val and GSTT null may be associated with individual susceptibility to formation of DNA adducts.

It was recently reported that a high hemoglobin adduct level is associated with NAT2 slow acetylator in low dose cigarettes smokers ${ }^{36)}$. Hou et al. found that subjects with a combination of GSTM1 null and NAT2 slow acetylator had higher DNA adduct level than subjects with GSTM1 null and NAT2 rapid acetylators, but the difference was not statistically significant. Moreover, their results indicated that among slow acetylators, individuals with GSTM1 null had a significantly higher DNA adduct level than those with GSTM1 present ${ }^{8}$. On the other hand, it has been reported that polymorphism of NAT2 did not affect adduct levels in bus drivers ${ }^{17}$.

In our study, smokers with NAT2 SS genotype had significantly higher DNA adduct levels than those with RS or RR genotypes among GSTM1 or T present groups. Smokers with NAT2 SS genotype may be highly susceptible to carcinogen exposure. Unfortunately, this result was obtained for GSTM1 or T present smokers, not null smokers (Fig. 3 and Fig. 4). The combined effects of NAT2 and GSTT genotypes on DNA adducts have not been reported. In NAT2 RR or RS genotype group, the smokers with GSTT null had a significantly higher DNA adduct level than the smokers with GSTT present.

It has been reported that individuals with ALDH2 A1/A2 who consume alcohol regularly have a significantly higher frequency of sister chromatic exchange and higher 8hydroxyguanosine levels than other groups ${ }^{37,38)}$. It has been demonstrated that the ALDH2 genotypes significantly affect hemoglobin-associated acetaldehyde levels in blood ${ }^{39}$. In the present study, we found that smokers with ALDH2 A1/ A2 genotype have a significantly higher level of DNA adducts than smokers with ALDH2 A2/A2 genotype, but there was no significant difference between $\mathrm{A} 1 / \mathrm{A} 2$ and $\mathrm{A} 1 / \mathrm{A} 1$. These results suggest that ALDH2 polymorphism may influence DNA adduct level or DNA damage in smokers.

Experimental studies have indicated that $\beta$-carotene and $\alpha$-tocopherol can inhibit mutagenesis in bacterial systems ${ }^{40)}$, reduce chemically induced neoplasia ${ }^{41,42)}$, and prevent malignant transformation of cell cultures $\left.{ }^{43}, 44\right)$. Early epidemiological studies indicated that $\beta$-carotene and $\alpha$ tocopherol decrease lung cancer risk and total mortality ${ }^{45-48)}$, but recently, trials involving a large number of human subjects have shown that $\beta$-carotene and $\alpha$-tocopherol supplement increase the incidence of lung cancer and total mortality in cigarette smokers ${ }^{49}$. Grinberg-Funes et al. ${ }^{22)}$ found that PAHDNA adducts were inversely correlated with serum cholesterol-adjusted vitamin E levels. The correlation was limited to subjects with GSTM1 null genotype, and no association between PAH-DNA adducts and serum $\beta$ carotene levels was found. Another study by the same group showed that PAH-DNA adducts were inversely correlated with plasma levels of $\beta$-carotene ${ }^{24)}$. This correlation was 
significant only in subjects with GSTM1 null, indicating that $\alpha$-tocopherol had a significant protective effect on DNA adducts in subjects with low $\beta$-carotene level.

Our present results obtained in a Japanese population showed no significant correlation between plasma $\beta$-carotene or $\alpha$-tocopherol level and DNA adduct level in smokers or nonsmokers. However, a tendency for smokers with CYP1A1 Val/Val genotype to a higher DNA adduct level than those with Ile/Val and Ile/Ile genotypes was found in the low $\beta$-carotene group. In smokers with CYP1A1 Ile/Ile genotype, the DNA adduct level of the high $\beta$-carotene group was significantly higher than that of the low $\beta$-carotene group (Fig. 5). Smokers with GSTT null in the high plasma $\beta$ carotene group tended to have a higher DNA adduct level than those with GSTT present $(\mathrm{P}=0.07, \mathrm{n}=35)$ and those in the low $\beta$-carotene group $(\mathrm{p}=0.07, \mathrm{n}=31$ ) (Fig. 6). These results indicated that there was an interaction between CYP1A1 and GSTT genotypes with respect to plasma $\beta$ carotene levels. $\beta$-carotene may mediate the effects of polymorphism of CYP1A1 and GSTT on DNA adducts in smokers.

Our present data obtained from nonsmokers indicate that neither genetic polymorphisms of metabolic enzymes, nor levels of plasma $\beta$-carotene and $\alpha$-tocopherol influence the levels of lymphocyte DNA adducts. The relatively low exposure to carcinogens of subjects in this study may explain these results.

In conclusion, smokers with CYP1A1 exon $7 \mathrm{Val} / \mathrm{Val}$ and GSTM1 null genotype had a significantly higher DNA adduct level than those with other genotypes of CYP1A1 and GSTM1 null. Smokers with such genotypes may be more susceptible to carcinogens that cause DNA damage and lung cancer. Polymorphism of GSTT, NAT2, and ALDH2 may modulate DNA damage. Plasma $\beta$-carotene may influence DNA damage due to carcinogens by interaction with genotypes of CYP1A1 and GSTT. Genetic polymorphism of CYP1A1, GSTM1, T, NAT2, and ALDH2, as well as plasma $\beta$-carotene level and cigarette smoking, may contribute to individual susceptibility to DNA damage and lung cancer.

\section{Acknowledgments}

We thank Mrs. K. Takahashi for her technical assistance. This study was supported in part by a grant-in-aid (No. 09470102) for Scientific Research from the Ministry of Education, Science, Sport and Culture, Japan.

\section{References}

1) Hayashi S, Watanabe J, Kawajiri K (1992) High susceptibility to lung cancer analyzed in terms of combined genotype of P4501 A1 and Mu-class glutathione S-transferase genes. Jpn J Cancer Res 83, 866-70.

2) Nakachi K, Imai K, Hayashi S, Kawajiri K (1993) Polymorphism of the CYP1A1 and glutathione Stransferase genes associated with susceptibility to lung cancer in relation to cigarette dose in a Japanese population. Cancer Res 53, 2994-9.

3) Hirvonen $A$, Husgafvel-Pursiainen $K$, Karjalainen A, Anttila S, Vainio H (1992) Point-mutational MspI and Ile-Val polymorphism closely linked in the CYP1A1 gene: lack of association with susceptibility to lung cancer in a Finnish study population. Cancer Epidemiol Biomarkers Prevent 1, 485-9.

4) Shields PG, Caporaso NE, Falk RT, Sugimura H, Trivers GE, Trump BF, Hoover RN, Weston A, Harris CC (1993) Lung cancer, race, and a CYP1A1 genetic polymorphism. Cancer Epidemiol Biomarkers Prevent 2, 481-5.

5) Zhong S, Howie AF, Ketterer B, Taylor J, Hayes JD, Beckett GJ, Wathen CG, Wolf CR, Spurr NK (1991) Glutathione S-transferase mu locus: use of genotyping and phenotyping assays to assess association with lung cancer susceptibility. Carcinogenesis 9, 1533-7.

6) Alexandrie AK, Sundberg MI, Seidegard J, Tornling G, Rannug A (1994) Genetic susceptibility to lung cancer with special emphasis on CYP1A1 and GSTM1: a study on host factors in relation to age at onset, gender and histological cancer types. Carcinogenesis 15, 178590.

7) Ichiba M, Hagmar L, Rannug A, Högstedt B, Alexandrie A, Carstensen U, Hemminki K (1994) Aromatic DNA adducts, micronuclei and genetic polymorphism for CYP1A1 and GST1 in chimney sweeps. Carcinogenesis 15, 1347-52.

8) Hou SM, Lambert B, Hemminki K (1995) Relationship between hprt mutant frequency, aromatic DNA adducts and genotypes for GSTM1 and NAT2 in bus maintenance workers. Carcinogenesis 16, 1913-7.

9) Ryberg D, Skaug V, Hewer A, Phillips DH, Harries LW, Wolf CR, Øgreid D, Ulvik A, Vu P, Haugen A (1997) Genotypes of glutathione transferase $\mathrm{M} 1$ and $\mathrm{P} 1$ and their significance for lung DNA adduct levels and cancer risk. Carcinogenesis 18, 1285-9. 
10) Pemble $S$, Schroeder KR, Spencer SR, Meyer DJ, Hallier E, Bolt HM, Ketterer B, Taylor JB (1994) Human glutathione S-transferase theta (GSTT1): cDNA cloning and the characterization of a genetic polymorphism. Biochem J 300, 271-6.

11) Nelson HH, Wiencke JK, Christiani DC, Cheng TJ, Zuo ZF, Schwartz BS, Lee BK, Spitz MR, Wang M, $\mathrm{Xu} X$, Kelsey KT (1995) Ethnic differences in the prevalence of the homozygous deleted genotype of glutathione S-transferase theta. Carcinogenesis 16, 1243-5.

12) Schröder KR, Wiebel FA, Reich $S$, Dannappel $D$, Bolt HM, Hallier E (1995) Glutathione-S-transferase (GST) theta polymorphism influences backgroud SCE rate. Arch Toxicol 69, 505-7.

13) Hallier E, Langhof T, Dannappel D, Leutbecher M, Schroeder K, Goergens HW, Muller A, Bolt HM (1993) Polymorphism of glutathione conjugation of methyl bromide, ethylene oxide and dichloromethane in human blood; Influence on the induction of sister chromatid exchange (SCE) in Lymphocytes. Arch Toxicol 67, 1738.

14) Ichiba $M$, Wang $Y$, Oishi $H$, Zhang J, Iyadomi $M$, Minagawa M, Tomokuni K (1998) Lymphocytes, DNA adducts and genetic polymorphism for metabolic enzymes in low dose cigarette smokers. Biomarkers 3, 63-71.

15) Nebert DW (1991) Role of genetics and drug metabolism in human cancer risk. Mutat Res 247, 267-81.

16) Minchin RF, Kadlubur FF, Ilet FF (1993) Role of acetylation in colorectal cancer. Mutat Res 290, 35-42.

17) Nielsen PS, Pater ND, Okkels H, Autrup H (1996) Environmental air pollution and DNA adducts in Copenhagen bus drivers-Effect of GSTM1 and NAT2 genotypes on adduct levels. Carcinogenesis 17, 10217.

18) Yokoyama A, Muramatsu T, Ohmori T, Higuchi $S$, Hayashida M, Ishii H (1996) Esophageal cancer and aldehyde dehydrogenase-2 genotypes in Japanese males. Cancer Epidemiol Biomarkers Prev 5, 99-102.

19) Wickramasinghe $S N$, Gardner B, Barden G (1986) Cytotoxic protein molecules generated as a consequence of ethanol metabolism in vitro and in vivo. Lancet 2 , 823-6.

20) Fang JL, Vaca CE (1995) Development of a ${ }^{32} \mathrm{P}$ postlabeling method for the analysis of adducts arising through the reaction of acetaldehyde with 2'deoxyguanosine-3'-monphosphate and DNA.
Carcinogenesis 16, 2177-85.

21) Woutersen RA, Appelman LM, Van GHA, Feron VJ (1986) Inhalation toxicity of acetaldehyde in rats, III, Carcinogenicity study. Toxicology 41, 213-31.

22) Grinberg-Funes RA, Singh VN, Perera FP, Bell DA, Young TL, Dickey C, Wang LW, Santella RM (1994) Polycyclic aromatic hydrocarbon-DNA adducts in smokers and their relationship to micronutrient levels and the glutathione-S-transferase M1 genotype. Carcinogenesis 15, 2449-54.

23) Wang Y, Ichiba M, Oishi H, Iyadomi M, Shono N, Tomokuni K (1997) Relationship between plasma concentrition $\beta$-carotene and $\alpha$-tocopherol and life-style factors and levels of DNA adducts in lymphocytes. Nutr Cancer 27, 69-73.

24) Mooney LA, Bell DA, Santella R, Bennekum AMV, Ottman R, Paik M, Blaner WS, Lucier GW, Covey L, Young TL, Cooper TB, Glassman AH, Perera FP (1997) Contribution of genetic and nutritional factors to DNA damage in heavy smokers. Carcinogenesis 18, 503-9.

25) Matsuura T, Ueyama $H$, Nomi S, Ueda K (1979) Effect of $\alpha$-tocopherol on the binding of benzo (a) pyrene to nuclear macromolecules. J Nutr Sci Vitam 25, 495-504.

26) Tan B, Chu FL (1991) Effects of palm carotenoids in rat hepatic cytochrome $\mathrm{P}-450$-mediated benzo (a) pyrene metabolism. Am J Clin Nutr 53, 1071S-5S.

27) Das SK, Jia TZ, Bandyopadhyay AM, Banerjee MR (1992) $\beta$-carotene-mediated Inhibition of a DNA adduct induced by 7, 12-dimethylbenz (a) anthracene and 7hydroxymethyl-12-methylbenz (a) anthracene in mouse mammary gland in vitro. Eur J Cancer 28A, 1124-9.

28) Miller KW, Lorr NA, Yang CS (1984) Simultaneous determination of plasma retinol, $\alpha$-tocopherol, lycopene, $\alpha$-carotene, and $\beta$-carotene by high-performance liquid chromatography. Anal Biochem 138, 340-5.

29) Miller KW, Yang CS (1985) An isocratic highperformance liquid chromatography method for the simultaneous analysis of plasma retinol, $\alpha$-tocopherol and various carotenoids. Anal Biochem 145, 21-6.

30) Yamano $Y$, Tokutake T, Haga M, Ishihara $Y$, Morinobu S, Kagawa J (1990) Determination of cotinine by high performance liquid chromatography and evaluation of exposure to tabacco smoke. Proceedings of 63rd Annual Meeting of Japan Association of Industrial Health. 126 (In Japanese).

31) Kendall TL, Byerley DJ, Dean R (1991) Isolation of DNA from Blood. Anal Biochem 195, 74-6.

32) Reddy MV, Randerath K (1986) Nuclease P1-mediated 
enhancement of sensitivity of ${ }^{32} \mathrm{P}$-postlabeling test for structurally diverse DNA adducts. Carcinogenesis 7, 1543-51.

33) Oyama T, Mitsudomi T, Kawamoto T, Ogami A, Osaki T, Kodama Y, Yasumoto K (1995) Detection of CYP1A1 gene polymorphism using designed RFLP and distributions of CYP1A1 genotypes in Japanese. Int Arch Occup Environ Health 67, 253-6.

34) Groppi A, Coutelle C, Fleury B, Iron A, Begueret J, Couzigou P (1991) Glutathione S- transferase class $\mu$ in Frence alcoholic cirrhotic patients. Hum Genet 87, 628-30.

35) Takeshita T, Morimoto K, Mao $X$, Hashimoto $T$, Furuyama $J$ (1994) Characterization of the three genotypes of Low $\mathrm{K}_{\mathrm{m}}$ aldehyde dehydrogenase in a Japanese population. Hum Genet 94, 217-23.

36) Vineis P, Bartsch H, Caporaso N, Harrington AM, Kadlubar FF, Landi MT, Malaveille C, Shields PG, Skipper P, Talaska G, Tannenbaum SR (1994) Genetically based N-acetyltransferase metabolic polymorphism and low-level environmental exposure to carcinogens. Nature 369, 154-6.

37) Morimoto $K$, Takeshita $T$ (1996) Low $K_{m}$ aldehyde dehydrogenase (ALDH2) polymorphism, alcoholdrinking behavior, and chromosome alteration in peripherol lymphocytes. Environ Health Perspect 104, 563-7.

38) Nakajima $M$, Takeuchi $T$, Takeshita $T$, Morimoto $K$ (1996) 8-Hydroxydeoxy-guanosine in human leukocyte DNA and daily health practice factors: effects of individual alcohol sensitivity. Environ Health Perspect 104, 1336-8.

39) Takeshita T, Kawai T, Morimoto K (1997) Elevated levels of hemoglobin-associated acetadehyde related to alcohol drinking in the atypical genotype of low $\mathrm{K}_{\mathrm{m}}$ aldehyde dehydrogenase. Cancer Res 57, 1241-3.

40) Ong T, Whong WZ, Stewart JD, Brockman HE (1989) Comparative antimutagenicity of 5 compounds against
5 mutagenic complex mixtures in salmonella typhimurium strain TA98. Mutat Res 222, 19-25.

41) Steinel HH, Baker RS (1990) Effects of $\beta$-carotene on chemically-induced skin tumors in HRA/SKH hairless mice. Cancer Lett 51, 163-8.

42) Lambert LA, Koch WH, Wamer WG, Kornhauser A (1990) Antitumor activity in skin of SKH and sencar mice by two dietary $\beta$-carotene formulation. Nutr Cancer 13, 213-21.

43) Alam BS, Alam SQ (1987) The effect of different levels of dietary $\beta$-carotene on DMBA-induced salivary gland tumors. Nutr Cancer 9, 93-101.

44) Bertram JS, Pung A, Churley M, Kappock TJ4d, Wilkins LR, Cooney RV (1991) Diverse carotenoids protect against chemically induced neoplastic transformation. Carcinogenesis 12, 671-8.

45) Peto R, Doll R, Buckley JD, Sporn MB (1981) Can dietary $\beta$-carotene materially reduce human cancer rates? Nature 290, 201-8.

46) Ziegler RG, Subar AF, Craft NE, Ursin G, Pattenson BH, Graubard BI (1992) Does $\beta$-carotene explain why reduced cancer risk is associated with vegetable and fruit intake? Cancer Res 52, 2060s-6s.

47) Mayne ST, Janerich DT, Greenwald P, Chorost S, Tucci C, Zaman MB, Melamed MR, Kiely M, McKneeally MF (1994) Dietary $\beta$-carotene and lung cancer risk in U.S. nonsmokers. JNCI 86, 33-8.

48) Blot WJ, Li JY, Taylor PR, Guo W, Dawsey S, Wang GQ, Yang CS, Zhang ST, Gail M, Li GY, Yu Y, Liu B, Tangrea J, Sun Y, Liu F, Fraumeni JRJF, Zhang Y, Li B (1993) Nutrition intervention trials in Linxian, China: supplementation with specific vitamin/mineral combinations, cancer incidence, and disease-specific mortality in the general population. JNCI 85, 1483-92.

49) The alpha-tocopherol, beta-carotene cancer prevention study group (1994) The effect of vitamin $\mathrm{E}$ and $\beta$ carotene on the incidence of lung cancer and other cancers in male smokers. N Engl J Med 330, 1029-35. 